\title{
PELATIHAN KOMBINASI POWER TRAINING DAN CALF RAISES LEBIH MEMPERCEPAT WAKTU TEMPUH MEMANJAT DARIPADA POWER TRAINING DAN HAND GRIP PADA ATLET PEMANJAT TEBING FPTI KABUPATEN KARANGASEM BALI
}

\author{
Putu Wandari Pranitha', I Putu Gede Adiatmika ${ }^{2}$, Sugijanto ${ }^{3}$, I Made Krisna Dinata ${ }^{4}$, Bagus \\ Komang Satriyasa ${ }^{5}$, Luh Made Indah Sri Handari Adiputra ${ }^{6}$ \\ ${ }^{1}$ Program Studi Magister Fisiologi Keolahragaan Universitas Udayana, Denpasar \\ 2,4,6 Departemen Ilmu Faal Fakultas Kedokteran Universitas Udayanan, Denpasar \\ ${ }^{3}$ Fakultas Fisioterapi Universitas Esa Unggul, Jakarta \\ ${ }^{5}$ Departemen Farmakologi Fakultas Kedokteran Universitas Udayana, Denpasar
}

e-mail : wandapranitha@gmail.com

\begin{abstract}
ABSTRAK
Waktu tempuh memanjat sangat menentukan kemenangan bagi atlet panjat tebing kategori speed world record, oleh sebab itu peningkatan kondisi fisik seperti power lengan dan tungkai serta kekuatan daya tahan jari-jari tangan dan kaki diperlukan untuk mendukung mempercepat waktu pemanjatan. Tujuan Penelitian adalah untuk mengetahui pelatihan kombinasi power training dan calf raises lebih mempercepat waktu tempuh memanjat daripada power training dan hand grip. Penelitian ini bersifat eksperimental dengan rancangan randomized pre-test and post test group design. Sampel sebanyak 20 atlet perempuan berusia 15-20 tahun, dibagi menjadi 2, Kelompok I (power traning dan hand grip) sebanyak 10 orang dan Kelompok II (power traning dan calf raises) sebanyak 10 orang. Penelitian dilaksanakan selama 6 minggu dan pengukuran dilakukan dengan mengukur waktu tempuh memanjat menggunakan stopwatch. Hasil yang didapat dari uji paired sample t-test pada Kelompok I didapatkan nilai $\mathrm{p}=0,000(\mathrm{p}<0,05)$, dan pada Kelompok II didapatkan nilai $\mathrm{p}=0,000(\mathrm{p}<0,05)$. Uji beda nilai rerata dengan independent sample t-test setelah perlakuan didapatkan waktu tempuh memanjat tebing pada Kelompok II $(10,6 \pm 0,966)$ lebih cepat daripada kelompok I $(12,1 \pm 1,449)$ dengan nilai $\mathrm{p}=0,014(\mathrm{p}<0,05)$. Dapat disimpulkan bahwa pelatihan kombinasi power training dan calf raises lebih mempercepat waktu tempuh memanjat daripada power training dan hand grip pada atlet pemanjat tebing FPTI Kabupaten Karangasem Bali.
\end{abstract}

Kata Kunci : power training, hand grip, calf raises, waktu tempuh memanjat tebing

\section{COMBINATION TRAINING OF POWER TRAINING AND CALF RAISES MORE SPEED UP THE CLIMBING TIME THAN POWER TRAINING AND HAND GRIP ON FPTI CLIMBER ATHLETES IN KARANGASEM REGENCY, BALI}

\begin{abstract}
Climbing time very determine victory for climbing athletes in the speed world record category. Therefore, an increase in physical conditions such as arm and leg power and endurance of the fingers and toes is needed to support speeding up the climbing time. Research aims to understand power training and calf raises more speed up climbing time than power training and hand grip. The research method is experimental with a randomized pre-test and post-test two group design. A sample of 20
\end{abstract}


female athletes, aged 15-20 years. Sample were divided into two group, group I (power training and hand grip) of 10 people and group II (power training and calf raises) of 10 people. The study was conducted for 6 weeks and measurement the climbing time using a stopwatch. The results obtained from the paired sample t-test on the group I obtained value $\mathrm{p}=0.000(<0.05)$ and on the group II obtained value $\mathrm{p}=0.000(<0.05)$. Mean different with independent sample t-test after training in group II (10.6 \pm 0.966$)$ more speed up climbing time than group I $(12.1 \pm 1.449)$ with $\mathrm{p}=0.014(\mathrm{p}<$ $0.05)$. It's concluded that power training and calf raises more speed up the climbing time than power training and hand grip on FPTI climber athletes in Karangasem, Bali.

Keyword : power training, hand grip, calf raises, climbing time.

\section{PENDAHULUAN}

Olahraga prestasi yang ada di Indonesia salah satunya adalah panjat tebing. Olahraga ini memiliki tiga kategori perlombaan seperti boulder, lead dan speed. Setiap kategori memiliki tingkat kesulitan yang berbeda-beda. Hasil pengamatan di lapangan menunjukkan, prestasi atlet Federasi Panjat Tebing Indonesia (FPTI) Kabupaten Karangasem Bali mengalami penurunan, seperti pada kejuaraan Porprov 2019 terutama pada kategori speed world record. Hasil catatan waktu tempuh memanjat yang diperoleh atlet kurang maksimal yaitu masih di bawah kategori baik atau lebih dari 16 detik.

Kategori speed diperlombakan menggunakan dinding panjat buatan yang dirancang berdasarkan spesifikasi yang mengacu pada International Federation of Sport Climbing (IFSC) Speed Licence, dengan menggunakan sistem pencatatan waktu otomatis, atlet diamankan dari atas menggunakan automatic belay system yang telah memenuhi standar IFSC. 1 Speed world record merupakan kategori yang point panjatnya mempunyai bentuk atau karakter yang khusus dan tinggi rute pemanjatan haruslah 10-15 meter serta kemiringan/ overhang dinding harus maksimal $5^{\circ} .^{2}$

Terjadinya penurunan prestasi disebabkan karena atlet yang jarang mengikuti latihan atau disebabkan karena kurang adanya pengembangan latihan yang berguna untuk pengembangan kondisi fisik. Kondisi fisik yang harus dimiliki adalah anthopometry, daya tahan, kekuatan dan kecepatan. $^{34}$

Kekuatan otot anggota gerak atas dibutuhkan untuk mengangkat atau menarik tubuh ke atas, sedangkan kekuatan otot anggota gerak bawah dibutuhkan untuk mendorong tubuh ke atas, namun untuk mempercepat waktu pemanjatan dibutuhkan juga kecepatan gerak. ${ }^{5}$ Kekuatan otot dan kecepatan harus dikerahkan secara maksimal untuk bisa mempercepat waktu pemanjatan. ${ }^{6}$ Komponen kekuatan jika digabungkan dengan kecepatan akan menghasilkan power otot. $^{7}$

Otot tidak hanya membutuhkan kekuatan untuk dapat bergerak tetapi juga memerlukan daya tahan otot. Daya tahan otot jari-jari tangan dan kaki dibutuhkan dalam mendukung mempercepat waktu pemanjatan. Komponen tersebut dibutuhkan saat gerakan mencengkeram dan gerakan menumpu pada point panjatan. ${ }^{8}$

Power training terdiri dari latihan pull-up dan half squat jump. Pull-up merupakan bagian dari gerak "closed kinetic chain exercise (CKC) dan multi-joint upper-body exercise". Latihan pull-up dapat meningkatkan kekuatan bahu, stabilitas dan kemampuan untuk menghasilkan kekuatan maksimum selama aktivitas menarik seperti pada panjat tebing. ${ }^{9}$ Half squat jump adalah latihan dengan cara meloncat yang dilakukan secara cepat. Latihan ini bertujuan untuk meningkatkan power otot gluteus, gastrocnemius, quadrisep, hamstring dan fleksor hip. ${ }^{10}$ Peningkatan power otot akan lebih efektif jika diberikan pelatihan dengan model latihan pliometrik karena melibatkan sistem neuromuscular yakni gerakan yang terletak pada jalur refleks yaitu refleks regang pada serabut otot (stretch refleks). ${ }^{11}$

Hand grip exercise adalah latihan yang digunakan untuk meningkatkan kekuatan dan daya tahan genggaman/cengkeraman otot jarijari tangan dengan cara memegang hand 
gripper dan kemudian menarik/meremas hand gripper dengan kedua tangan. 12

Calf raises exercise adalah latihan yang bertujuan untuk meningkatkan kekuatan dan daya tahan otot gastrocnemius dan plantar fleksor serta memperbaiki keseimbangan yang dilakukan dengan cara berdiri di ujung tangga atau box kemudian mengangkat tumit/ankle sampai berdiri dengan ujung kaki, pertahankan posisi lalu perlahan kembali ke posisi semula. ${ }^{13}$

Pelatihan dengan menggunakan latihan beban bertujuan untuk meningkatkan jumlah dan ukuran myofibril per serabut otot, meningkatkan total jumlah protein kontraktil, meningkatkan kepadatan kapiler per serabut otot dan meningkatkan kandungan protein mitokondria. ${ }^{14}$

Semua unsur di atas selalu berikatan satu sama lain guna mencapai prestasi sesuai dengan cabang olahraganya. Pada umumnya pelatih dan pembina olahraga sudah mengetahui komponen kondisi fisik yang diperlukan atletnya, namun pengetahuan tersebut belum ditunjang oleh kemampuan untuk mengetahui komponen mana yang menjadi sumbangan terbesar yang diperlukan atlet dan memilih latihan yang diperlukan terutama pada olahraga panjat tebing kategori speed, oleh karena itu dilakukan penelitian untuk membuktikan pelatihan kombinasi power training dan calf raises lebih mempercepat waktu tempuh memanjat daripada power training dan hand grip pada atlet pemanjat tebing FPTI Kabupaten Karangasem Bali.

\section{METODE PENELITIAN}

Penelitian ini dilaksanakan di Gor Gunung Agung, jalan Padang Kerta, Kecamatan Karangasem, Provinsi Bali pada bulan Januari sampai Februari 2020. Rancangan penelitian ini bersifat eksperimental dengan rancangan pretest and post-test group design. Sampel dibagi menjadi dua kelompok yang dilakukan secara acak atau random.

\section{Sampel dan Populasi}

Kriteria sampel pada penelitian ini diperoleh dari populasi yang sesuai dengan kriteria eksklusi dan inklusi, sedangkan besar dari sampel ditentukan dari hasil penelitian terdahulu yang dihitung melalui rumus pocock sehingga didapatkan 9 orang dan untuk mengantisipasi drop out sampel ditambah $10 \%$ sehingga berjumlah 10 orang per kelompok. Kelompok I diberikan pelatihan kombinasi power training dan hand grip, sedangkan Kelompok II diberikan pelatihan power training dan calf raises. Penelitian dilakukan dengan frekuensi sebanyak tiga kali seminggu yang berlangsung selama 6 mingggu.

\section{Pengumpulan Data Penelitian}

Meminta persetujuan kepada sampel dengan penjelasan secara lisan serta tulisan mengenai maksud dan tujuan penelitian dan hak yang diperoleh oleh sampel. Selanjutnya melaksana-kan tes awal yaitu mengukur kondisi fisik sampel seperti kekuatan dan power lengan dengan tes pull-up, power tungkai dengan standing broad jump test, kekuatan cengkeraman jari-jari tangan dengan hand dynamometer, kekuatan daya tahan kaki dengan calf raises test dan pengukuran waktu tempuh memanjat tebing dengan stopwatch. Kemudian setelah 6 minggu dilakukan pengukuran kembali waktu tempuh memanjat tebing dengan stopwatch.

\section{HASIL PENELITIAN}

\section{A. Karakteristik Subjek Penelitian}

Penelitian ini memiliki karakteristik subjek yang dibagi menjadi dua yaitu data umum dan data kondisi fisik. Data umum subjek penelitian terdiri dari usia, tinggi badan, berat badan, IMT dan VO2maks, sedangkan data kondisi fisik terdiri dari kekuatan lengan (pull-up), power tungkai, kekuatan cengkeraman tangan kanan dan kiri, kekuatan daya tahan kaki dan waktu tempuh memanjat tebing. Kemudian ke dua data karakteristik subjek diuji menggunakan Independent Sampel t-test dan didapatkan hasil nilai $\mathrm{p}>0,05$. Artinya data antara kedua kelompok memiliki karakteristik yang hampir sama.

\section{B. Uji Normalitas dan Homogenitas}

Hasil uji normalitas waktu tempuh memanjat tebing memiliki nilai $\mathrm{p}>0,05$, artinya seluruh data pada masing-masing kelompok berdistribusi normal. Hasil uji homogenitas waktu tempuh memanjat tebing 
dengan menggunakan Levene's test didapatkan nilai $\mathrm{p}=0,712(\mathrm{p}>0,05)$, artinya seluruh data bersifat homogen.

\section{Uji Perbedaan Waktu Tempuh Memanjat Tebing Sebelum dan Sesudah diberikan Perlakuan Pada Kelompok I dan II}

Tabel 1 menunjukkan pelatihan kombinasi power training dan hand grip (Kelompok I) dapat mempercepat waktu tempuh memanjat pada atlet pemanjat tebing dengan nilai $\mathrm{p}=$ $0,000$ ( $\mathrm{p}>0,05)$, serta pelatihan kombinasi power training dan calf raises (Kelompok II) dapat mempercepat waktu tempuh memanjat pada atlet pemanjat tebing dengan nilai $\mathrm{p}=$ $0,000(\mathrm{p}>0,05)$.

Tabel 1.

Paired Sampel t-test

\begin{tabular}{|c|c|c|c|}
\hline \multirow[t]{2}{*}{ Kelompok } & \multicolumn{2}{|c|}{$\begin{array}{c}\text { Waktu Tempuh Memanjat } \\
\text { Tebing }\end{array}$} & \multirow[t]{2}{*}{$\begin{array}{c}\text { Nilai } \\
\mathrm{p}\end{array}$} \\
\hline & $\begin{array}{c}\text { Pre-test } \\
\text { Rerata } \pm \mathrm{sd}\end{array}$ & $\begin{array}{c}\text { Post-test } \\
\text { Rerata } \pm \\
\text { sd }\end{array}$ & \\
\hline Kelompok I & $17,1 \pm 1,101$ & $\begin{array}{l}12,1 \pm \\
1,449\end{array}$ & 0,000 \\
\hline Kelompok II & $17,3 \pm 1,160$ & $\begin{array}{l}10,6 \pm \\
0,966\end{array}$ & 0,000 \\
\hline
\end{tabular}

\section{Uji Beda Rerata Waktu Tempuh Memanjat Tebing Pada Kelompok Perlakuan I dan II}

Tabel 2 menunjukkan ada perbedaan yang bermakna antara waktu tempuh memanjat tebing dari hasil setelah diberikan pelatihan pada Kelompok I dan Kelompok II dengan nilai $\mathrm{p}=0,014(\mathrm{p}<0,05)$. Rerata waktu tempuh memanjat tebing pada Kelompok II yaitu 10,6 detik lebih cepat waktu tempuh memanjatnya daripada rerata waktu tempuh memanjat tebing pada Kelompok I yaitu 12,1 detik.

\section{Tabel 2}

Independent Sampel t-test

\begin{tabular}{lccc}
\hline \multirow{2}{*}{ Kelompok } & \multicolumn{3}{c}{ Waktu Tempuh Memanjat Tebing } \\
\cline { 2 - 4 } & Pre-test & Post-test & Selisih \\
& Rerata \pm sd & Rerata \pm sd & Rerata \pm sd \\
\hline Kelompok I & $17,1 \pm 1,101$ & $12,1 \pm 1,449$ & $5,0 \pm 1,563$ \\
Kelompok II & $17,3 \pm 1,160$ & $10,6 \pm 0,966$ & $6,7 \pm 1,636$ \\
Nilai p & 0,697 & 0,014 & 0,029 \\
\hline
\end{tabular}

\section{PEMBAHASAN}

\section{A. Pelatihan Kombinasi Power Training dan Hand Grip serta Power Training dan Calf Raises dapat Mempercepat Waktu Tempuh Memanjat Pada Atlet Pemanjat Tebing FPTI Kabupaten Karangasem Bali.}

Power Training terdiri dari latihan pull-up dan half squat jump. Berdasarkan beberapa kajian teori, pull- up merupakan latihan yang dapat meningkatkan kekuatan bahu, stabilitas dan kemampuan untuk menghasilkan kekuatan maksimum selama aktivitas menarik, seperti panjat tebing, senam, mendayung dan berenang. ${ }^{9}$ Menurut hasil penelitian terdapat peningkatan power otot lengan setelah diberikan latihan pull-up. Semakin tinggi nilai power otot lengan maka semakin tinggi atau cepat waktu tempuh memanjat tebing. ${ }^{15}$

Latihan pull-up dapat mempercepat waktu tempuh memanjat tebing karena bentuk latihannya yang sesuai dengan gerakan memanjat tebing yaitu gerakan menarik badan ke atas. Latihan ini membentuk otot lengan dan tangan dalam meningkatkan kekuatan maksimal untuk menarik tubuh berpindah ke atas atau menggantung pada point panjatan. ${ }^{16}$

Latihan half squat jump dengan bentuk pelatihan pliometrik bertujuan untuk meningkatkan power tungkai saat gerakan awalan mendorong tubuh ke atas. ${ }^{17}$ Power otot tungkai memiliki hubungan yang positif dengan kemampuan memanjat kategori speed. Semakin tinggi nilai power otot tungkai maka semakin tinggi atau cepat waktu tempuh memanjat. ${ }^{15}$

Tambahan pelatihan pada Kelompok I yaitu hand grip exercise yang dilakukan dengan continue dapat meningkatkan kekuatan cengkeraman tangan. ${ }^{12}$ Latihan ini menyebabkan lebih banyak sintesis protein di otot dan meningkatkan total volume otot sehingga menjadikan kekuatan daya tahan otot meningkat. ${ }^{18}$ Kekuatan dan daya tahan cengkeraman tangan yang lebih tinggi menghasilkan kinerja pemanjatan yang lebih 
baik dan jari-jari tangan merupakan penentu untuk menyelesaikan rute pemanjatan.

Hand grip exercise juga berfungsi untuk mengaktivasi otot-otot lengan bawah dengan ko-kontraksi otot fleksor dan ektensor sehingga meningkatkan kekuatan cengkeraman tangan untuk membantu anggota gerak atas melakukan gerakan menggantung pada point dan berpindah dari point satu ke point yang lainnya serta mengurangi kelelahan tangan pada saat melakukan gerakan mencengkeram yang terus menerus dari point satu ke point yang lain. ${ }^{29} 20$

Sedangkan tambahan pelatihan pada Kelompok II yaitu calf raises dapat meningkatkan kekuatan dan daya tahan otot kaki, sehingga pada saat kaki melakukan gerakan pemanjatan tidak terjadi kelelahan yang berarti dan bisa membantu otot tungkai untuk mempercepat waktu pemanjatan. ${ }^{13} 21$ Latihan ini mengarahkan atlet untuk melakukan gerakan sesuai dengan gerakan pemanjatan pada kategori speed world record yaitu gerakan dorsal dan plantar flexi ankle. Sebelum memulai pemanjatan, kaki akan melakukan gerakan dorso fleksi ankle pada point panjatan, sedangkan kaki yang satunya akan melakukan gerakan plantar flexi ankle untuk memulai gerakan tolakan ke atas. ${ }^{8}$ Otot gastrocnemius dan soleus saat melakukan gerakan plantar fleksi ankle akan berkontraksi secara konsentrik sedangkan otot gastrocnemius dan soleus saat melakukan gerakan gerakan dorsi fleksi ankle akan berkontraksi secara eksentrik. Serat-serat otot pada saat kontraksi eksentrik akan tetap bereaksi melawan peregangan, sehingga selama gerakan eksentrik kekuatan otot yang dihasilkan akan lebih tinggi. ${ }^{22}$

Calf raises exercise dengan menggunakan ankle weight memiliki respon fisiologis pada sistem neuromuscular yang bertanggung jawab dalam motorisasi motorik, sehingga akan meningkatkan kapasitas jaringan otot dalam menyimpan energi dan meningkatkan sekresi neurotransmitter yang akan menghasilkan peningkatan daya tahan otot. ${ }^{23}$

\section{B. Pelatihan Kombinasi Power Training Dan Calf Raises Lebih Mempercepat Waktu Tempuh Memanjat Daripada Power Training Dan Hand Grip Pada}

\section{Atlet Pemanjat Tebing FPTI Kabupaten Karangasem Bali.}

Rerata waktu tempuh memanjat tebing setelah diberikan pelatihan pada Kelompok II waktu tempuh memanjatnya lebih cepat dari Kelompok I. Hal tersebut disebabkan karena power tungkai dan lengan merupakan subjek gerak yang dominan dalam panjat tebing karena sangat berarti pada melompat dan menambah ketinggian. ${ }^{16}$ Panjat tebing kategori speed lebih kondusif jika diberikan pelatihan power otot dan jika terjadi peningkatan power otot pada tungkai akan lebih mempercepat waktu tempuh memanjat tebing. ${ }^{24}$

Anggota gerak bawah memiliki kontribusi yang besar untuk membantu tubuh berpindah ke atas, terutama pada saat gerakan fleksi knee. ${ }^{8}$ Gerakan squat dengan fleksi knee dalam latihan half squat jump akan mengaktivasi otot rectus femori, bisep femoris, tibialis anterior dan otot soleus. Mengaktivasi otot ekstensor, hamstring, gluteus maksimus, dan adduktor saat melakukan gerakan half squat jump akan meningkatkan power tungkai untuk melakukan gerakan pemanjatan. ${ }^{25}$ Penambahan latihan calf raises pada latihan power otot akan lebih meningkatkan power otot pada tungkai, hal tersebut dikarenakan latihan calf raises dapat menyebabkan terjadi hipertropi otot dan membaiknya sistem saraf, serta meningkatnya protein kontraktil yang menyebabkan meningkatnya kekuatan otot. Gerakan kaki calf raise juga lebih banyak digunakan pada panjat tebing kategori speed karena dibutuhkan untuk membantu tungkai melakukan gerakan tolakan dan tubuh akan berpindah ke atas dengan cepat. ${ }^{26}$

Kekuatan cengkeraman juga dibutuhkan dalam pemanjatan, namun kekuatan tangan lebih dominan dibutuhkan pada panjat tebing kategori lead (rintisan) dan boulder (jalur pendek). Analisis hand grip lebih tinggi dibutuhkan pada kategori boulder $(22,0 \%)$ daripada lead $(12,2 \%)$ dan speed $(7,3 \%)$, hal tersebut dikarenakan pada kategori boulder cengkeraman tangan harus kuat dan mampu bertahan lama saat tubuh mengantung dan berpindah dari point satu ke point yang lainnya. ${ }^{27}$ 


\section{SIMPULAN}

1. Pelatihan kombinasi power training dan hand grip dapat mempercepat waktu tempuh memanjat pada atlet pemanjat tebing FPTI Kabupaten Karangasem Bali.

2. Pelatihan kombinasi power training dan calf raises dapat mempercepat waktu tempuh memanjat pada atlet pemanjat tebing FPTI Kabupaten Karangasem Bali.

3. Pelatihan kombinasi power training dan calf raises lebih mempercepat waktu tempuh memanjat daripada power training dan hand grip pada atlet pemanjat tebing FPTI Kabupaten Karangasem Bali.

\section{SARAN}

1. Pelatihan kombinasi power training dan calf raises sebaiknya diteruskan sebagai program untuk mempercepat waktu tempuh memanjat, meningkatkan komponen kondisi fisik dan dijadikan program latihan awal untuk pemula yang ingin melakukan olahraga panjat tebing.

2. Untuk peneliti selanjutnya agar mengontrol dengan semestinya latihan yang dilakukan selain latihan yang diberikan oleh peneliti.

\section{DAFTAR PUSTAKA}

1. Bidang Kompetisi PP, FPTI. 2019. Pedoman Penyelenggara Kompetisi Panjat Tebing. Available from : URL: www.FPTI.or.id (diakses 3 Maret 2020).

2. Bidang Kompetisi PP, FPTI. 2014. Pedoman Penyelenggara Kompetisi Panjat Tebing. Available from : URL: www.FPTI.or.id (diakses 3 Maret 2020).

3. Kozina, Zh.L., Ryepko, O.A., Prusik, Kr., Cieslica, M. 2013. Psychophysiological possibility of mountaineers and climbers specializing in speed climbing and climbing difficulty. Journal of MedicalBiological Problem Of Physical Training and Sport. No. 1: 41- 46. doi: 10.6084/m9.figshare.785784.
4. Kharkov, G.S., Ryepko, O.A. 2013. Morphological characteristics of elite athletes, specializing in speed climbing, climbing and alpinism. Journal of Medical-Biological Problem Of Physical Training and Sport. No. 1: 67-71. doi: $10.6084 / \mathrm{m} 9$. figshare.880621.

5. Dwikusworo, E.P. 2009. Tes dan Pengukuran Olahraga. Semarang : Fakultas Ilmu Keolahragaan. Universitas Negeri Semarang.

6. Ozimek, K., Krawczyk, M., Rokowski, R., Draga, P., Ambrozy, T., Mucha, D., Omrczk, J., Stanula, A., Pociecha, M., Gorner, K. 2018. Evaluation of the level of anaerobic power and its effect on speed climbing performance in elite climbers. Original Article Trends in Sport Sciences. Vol. 3. No. 25: 149-158. ISSN: 2299-9590 doi : 10.23829/TSS.2018.25.3-5.

7. Setyawan, R. 2012. Perbedaan Pelatihan Plyometric 5-5-5 Squat Jump Dengan Wave Squat Terhadap Peningkatan Power Otot Tungkai [tesis]. Surabaya : Program Pascasarjana Pendidikan Olahraga. Universitas Negeri Surabaya.

8. Nugroho, D. 2011. Analisis Gerak Dasar panjat tebing. Smart Sport Jurnal Kepelatihan Olahraga, Vol. 4. No. 2

9. Harman, E.A., Gutekunst, D.J., Frykman, P.N., Nindl, B.C., Aleman, J.A., Mello, R.P., Sharp, M.A. 2010. Effects of two different eight-week training programs on military physical performance. $J$ Strength Cond Res. Vol. 22: 524-534.

10. Sukadarwanto., Utomo, B. 2014. Perbedaan half squat jump dan knee tuck jump terhadap peningkatan daya ledak otot dan kelincahan. Jurnal Terpadu Ilmu Kesehatan. Vol. 3. No.2: 106-214.

11. Widhiyanti, K.A.T., Tirtayasa, K., Pangkahila, A. 2013. Pelatihan pliometrik alternate leg bound dan double leg bound meningkatkan daya ledak otot tungkai pada siswa putra kelas VII SMP Negeri 3 Sukawati tahun pelajaran 2012/2013. Sport 
and Fitness Journal. Vol. 1. No. 2. ISSN : 2302-688X.

12. Iskandar, T., Rahman, F., 2018. Pengaruh metode latihan hand grip terhadap kekuatan genggaman tangan pada atlet putra pelatcab petanque kota bekasi. Motion. Vol. 9. No. 2: 140-5.

13. Putra, S.S. 2015. Calf Raises Exercise Dan Ankle Hops Sama Baiknya Terhadap Peningkatan Daya Tahan Otot Gastrocnemius [skripsi]. Jakarta : Fakultas Fisioterapi. Universitas Esa Unggul.

14. Akhmad, I. 2015. Efek latihan berbeban terhadap fungsi kerja otot. Jurnal Pedagogik Keolahragaan. Vol. 1. No. 2: 80-102.

15. Widyarto, W. 2019. Hubungan Daya Ledak Otot Tungkai Dan Kekuatan Otot Lengan Dengan Kecepatan Memanjat Kategori Speed Pada Atlet Klub Olahraga Panjat Tebing Universitas Negeri Jakarta [tesis]. Jakarta : Universitas Negeri Jakarta

16. Abraham, H. 2012. Pengaruh latihan pull up dan latihan push up terhadap kemampuan panjat tebing kategori speed pada mahasiswa UNM. Competitor. No. 1: 20-32.

17. Hidayat, T. 2013. Pengaruh Latihan Pliometrik Terhadap Hasil Kecepatan Memanjat Cabor Panjat Tebing Kategori Speed [skripsi]. Bandung : Jurusan Pendidikan Kepelatihan Fakultas Pendidikan Olahraga dan Kesehatan. Universitas Pendidikan Indonesia.

18. Sathya, P., Kadhiravan, V., Poojary, P.P. 2016. Effect of resisted exercise versus free weight exercise for the improvement of grip strength of cricket players. International Journal of Advanced Research. Vol. 4. No. 7: 1193-8

19. Gürer, B., Yildiz, M.E. 2015. Investigation of Sport Rock Climbers Handgrip Strength. Biology of Exercise. Vol. 11. No. 2: $56-71$
20. Matsuka, O., Nani, S., Papadimitriou, K., Astrapellos, K., Beneka, A., Malliou, P. 2019. Time course changes in hand grip strength performance and hand position sense in climbing. Journal Of Human Sport $\&$ Exercise. doi:10.14198/jhse.2020.151.03.

21. Febriadi, F. 2017. Perbedaan Pengaruh Latihan Single Leg Speed Hop Dengan Latihan Knee Tuck Jump Terhadap Peningkatan Daya Ledak Otot Tungkai Pada Pemain Futsal [tesis]. Yogyakarta: Fakultas Ilmu Kesehatan. Universitas Aisyiyah.

22. Radford, J.A., Landorf, K.B., Buchbinder, R., Cook, C. 2007. Effectiveness of Calf Muscle Stretching for the Short-Term Treatment of Plantar Heel Pain. BMC Musculoskeletal Disorders, 8:36. Available from: URL : http://www.biomedcentral.com/14712474/8/36. (diakses 2 Mei 2020).

23. Ae-Rim, H., Sang-Min, H., Yun, A.S. 2014. Effects of resistance training on muscle strength, endurance, and motor unit according to ciliary neurotrophic factor polymorphism in male college students. Journal of Sports Science \& Medicine. Vol. 13. No. 3: 680-8

24. Ryepko, O.A. 2013. Features and functionality of speed and power capabilities of elite climbers and various types of rock climbing. Physical Education of Students. doi: 10.6084/m9.figshare.840505.

25. Ciccone, T., Davis, K., Baagley, J., Galpin, A. 2015. Deep squats and Knee Health: A Scientific Review. California State University. Available from: URL : https://shruggedcollective.com/wpcontent/uploads/2015/04/DeepSquatReview-Barbell-Daily-3-27-15.pdf. (diakses 23 Juni 2020)

26. Olexiy, S. 2014. Model characteristics of athletes-climbers specializing in speed climbing (format «record»). Sport Science 
Of Ukraine. No.59: 14-18. ISSN1: 9935757.

27. Salehhodin, S.N., Abdullah, B., Yusoff, A. 2017. Comparison level of handgrip strength for the three categories among male athlete's artificial wall climbing and factors will affect. International Journal of Academic Research in Business and Social Sciences. Vol. 7: 272-285. ISSN: 22226990. 